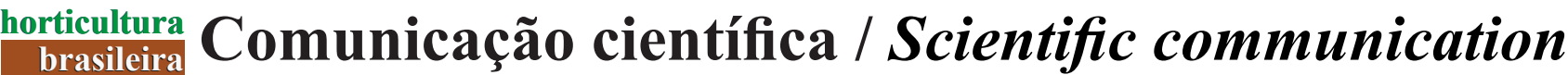

LIMA, IP; RESENDE, JTV; OLIVEIRA, JRF; FARIA, MV; DIAS, DM; RESENDE, NCV. 2016. Selection of tomato genotypes for processing with high zingiberene content, resistant to pests. Horticultura Brasileira 34: 387-391. DOI - http://dx.doi.org/10.1590/S0102-05362016003013

\section{Selection of tomato genotypes for processing with high zingiberene content, resistant to pests}

\author{
Isabela P Limaㅎ Juliano TV Resende ${ }^{2}$; João RF Oliveira²; Marcos V Faria ${ }^{2}$; Diego M Dias²; Nathalia CV \\ Resende $^{1}$ \\ ${ }^{1}$ Universidade Federal de Lavras (UFLA), Lavras-MG, Brasil; isabelailima@yahoo.com.br; nathaliacvr@yahoo.com.br; ${ }^{2}$ Universidade \\ Estadual do Centro-Oeste (UNICENTRO), Guarapuava-PR, Brasil; jvresende@uol.com.br; joaoroliveira@yahoo.com.br; ventura_ \\ faria@yahoo.com.br; diegomunhozdias@hotmail.com
}

\begin{abstract}
Tomato cultivars resistant to arthropod pests are an important tool to reduce the use of pesticides. Resistance sources can be found in wild Solanum species such as $S$. habrochaites, which shows high levels of zingiberene (ZGB). This study aimed to evaluate the resistance of a tomato $F_{2}$ progeny to spider mite and whitefly by evaluating the ZGB content, in laboratory, in plants from the $\mathrm{F}_{2}$ population of the interspecific crossing Solanum lycopersicum cultivar Redenção x Solanum habrochaites var. hirsutum (PI-127826), $F_{1}$ plants, susceptible plants (cultivar Redenção) and plants of the wild species (PI-127826). From the $\mathrm{F}_{2}$ population, six plants with high content and three with low content of ZGB were selected. For evaluating the impact of ZGB on the spider mite behavior, the distance walked by spider mites from a central point was measured on the selected plants and their parents. For whitefly, the number of eggs and nymphs were quantified. Spider mites travelled shorter distances in plants with high ZGB content. Also, the number of whitefly eggs and nymphs was lower in these plants. Higher ZBG contents affected negatively both the spider mite and the whitefly behavior.
\end{abstract}

Keywords: Solanum lycopersicum, Solanum habrochaites, allelochemicals, Tetranychus urticae, Bemisia tabaci.

\section{RESUMO}

Seleção de genótipos de tomateiro para processamento com alto teor de zingibereno resistentes a pragas

Cultivares de tomateiros resistentes a artrópodos-praga são uma importante ferramenta para a redução do uso de agrotóxicos nas lavouras. As fontes de resistência podem ser encontradas em espécies silvestres de Solanum, como o $S$. habrochaites, que apresenta altos teores de zingibereno (ZGB). Com o objetivo de avaliar a resistência ao ácaro-rajado e à mosca-branca em progênies $\mathrm{F}_{2}$ de tomateiro, foi quantificado o teor de ZGB em laboratório, em plantas da população $\mathrm{F}_{2}$ obtidas a partir do cruzamento interespecífico de Solanum lycopersicum cultivar Redenção x Solanum habrochaites var. hirsutum (PI-127826), em plantas $\mathrm{F}_{1}$, cultivar suscetível (Redenção) e em plantas da espécie silvestre (PI-127826). Da população $F_{2}$ foram selecionadas seis progênies para alto teor e três para baixo teor de ZGB. Para avaliar o impacto de ZGB sobre o comportamento do ácaro-rajado, mediu-se a distância percorrida pelo ácaro a partir de um ponto central nas plantas selecionadas e nos genitores. Já para moscabranca foram quantificados número de ovos e ninfas em folíolos. Os resultados demonstraram que em plantas com alto teor de ZGB os ácaros percorreram as menores distâncias. Já para mosca-branca foi encontrado menor número de ovos e ninfas nessas plantas. Assim, pode-se concluir que teores mais altos de ZGB afetam negativamente o comportamento do ácaro-rajado e da mosca-branca.

Palavras-chave: Solanum lycopersicum, Solanum habrochaites, aleloquímicos, Tetranychus urticae, Bemisia tabaci.

(Recebido para publicação em 13 de maio de 2015; aceito em 13 de janeiro de 2016) (Received on May 13, 2015; accepted on January 13, 2016)

$\mathrm{T}$ he tomato (Solanum lycopersicum) for processing is grown in most Brazilian regions all year long. Farmers grow 21.3 million hectares, with a production of 1.87 million tons. Brazil is the fifth largest producer worldwide representing about $5 \%$ of the world production. Also, this crop represents a great socio-economic importance in the Brazilian productive areas (WPTC, 2014).
Consumption of tomato-derived products has been increasing considerably in the latest years, the advancement of urbanization and the greater inclusion of women into the labor market being fundamental for this increase (Camargo et al., 2006). The increase of consumption requires a corresponding increase of production but pests have led to lower-thanexpected productivity, maintaining the high levels of tomato-derived products imports in Brazil (Nascimento et al., 2013).

Regarding pests which attack the tomato crop, the whitefly Bemisia tabaci Gennadius Biotype B (Hemiptera: Aleyrodidae) is considered a key pest due to its high damage potential and capacity to reduce yields under specific weather conditions. For mites of the genus Tetranychus, especially for $T$. 
urticae (Acari: Tetranychidae), despite being considered secondary pests, may cause serious damage under high infestation (Toscano et al., 2004; Maluf et al., 2007).

Pest management in tomato is usually carried out through chemical control, which may harm the farmer, the environment and the consumer (Silva et al., 2009). Breeding programs aim to develop cultivars resistant to these pests, the introgression of genes of wild species into commercial genotypes being used for this purpose. According to Weston et al. (1989), the wild species Solanum habrochaites var. hirsutum has been used due to the presence of sesquiterpenes called zingiberene (ZGB), which provide resistance of plants to pests. Some studies showed that high contents of this substance in tomato leaflets promote resistance to whitefly (Freitas et al., 2002; Neiva et al., 2013), as well as to tomato leafminer [Tuta absoluta (Lepidoptera: Gelechiidae)] (Azevedo et al., 2003; Oliveira et al., 2012) and spider mite (Maluf et al., 2001, 2007; Gonçalves et al., 2006).

According to Freitas et al. (2002), the $\mathrm{ZGB}$ content has monogenic inheritance with incomplete dominance towards lower content. However, the occurrence of modifier genes not ruled out. Freitas et al. (2002) also state that the inheritance has high heritability $\left(h^{2}=67.8 \%\right)$. These estimates allow greater success in breeding programs due to higher chances of gains in selections for high content of ZGB.

This study aimed to select plants with high ZGB content, resistant to spider mite and whitefly.

\section{MATERIAL AND METHODS}

The experiment was carried out in a greenhouse, in the Vegetable Crops Sector of the Department of Agronomy of the Centro-Oeste State University, in Guarapuava, Paraná State, Brazil. Interspecific cross Solanum lycopersicum cultivar Redenção $\mathrm{x}$ Solanum habrochaites var. hirsutum (PI127826) was carried out. The cultivar Redenção for industrial processing with resistance to geminivirus and tospovirus (Ferraz et al., 2003) being used as female genitor. Female-parent flowers were emasculated before anthesis, and open flowers of accession PI-127826 were collected for pollen extraction. Pollen extracted was, then, put in contact with the style stigma of the emasculated flowers. Pollinated flowers received marking to identify the crosses. $F_{1}$ seeds were extracted from the fruits obtained, sown in styrofoam trays and the seedlings transplanted into 10 $\mathrm{dm}^{3}$ capacity pots. The flowers of $F_{1}$ plants were self pollinated and from them, fruits containing $F_{2}$ seeds were collected.

All the plants used in the experiments, described as follows, were maintained in a greenhouse in $10 \mathrm{dm}^{3}$ capacity pots, containing a mixture of commercial substrate and soil in the proportion of 1:1, fertilized with N-P-K formulation 04-14-08 and limestone, according to the recommendation of Boletim 100 (Instituto Agronômico de Campinas, 1996), with daily irrigation.

\section{Experiment 1 - Quantification} of ZGB in the leaflets - the authors quantified the ZGB contents in the leaflets of 433 plants of $F_{2}$ population, 40 $\mathrm{F}_{1}$ plants, 40 plants of cultivar Redenção and 40 plants of the accession PI127826 at about 35 days after planting, according to the methodology proposed by Freitas et al. (2000). Six leaf discs of young expanded leaflets were collected from the upper third of the plants, totaling an area of $6 \mathrm{~cm}^{2}$, which were put in labeled test tubes. Then, $2 \mathrm{~mL}$ of hexane were added in each tube, stirred up in a magnetic stirrer (Vortex) for 40 seconds to promote the extraction of ZGB. After stirring, the leaf discs were removed and the solution obtained was submitted to absorbance reading using a spectrophotometer (Cary 60 UV-VIS), wavelength of $270 \mathrm{~nm}$, the absorbance being directly proportional to the amount of ZGB in leaf extract.

Based on the absorbance reading, the authors selected plants of $\mathrm{F}_{2}$ generation with contrasting ZGB contents (six with high content and three with low content) to be submitted to tests of resistance to spider mites and whitefly (experiments
2 and 3). To select contrasting genotypes within the segregating population, the authors used as criterion the average value of absorbance obtained from parents [S. habrochaites (high content of the allelochemical) and cultivar Redenção (low content)]. Contents of ZGB in selected plants were confirmed with three replications.

The selected plants were cloned through rooting of axillary shoots from the plants in styrofoam trays containing commercial substrate. Subsequently, they were transplanted into $5 \mathrm{dm}^{3}$ capacity pots, and kept in a greenhouse until the phenological stage of preflowering, with daily irrigation and without phytosanitary control.

Experiment 2 - Resistance to spider mite - The resistance to spider mite $T$. urticae was quantified through a bioassay proposed by Weston \& Snyder (1990). The mites used came from the nursery maintained in the Entomology Laboratory of the Agronomy Department of the Midwest Paraná State University, at temperature of $25 \pm 2^{\circ} \mathrm{C}$, humidity of $70 \pm 10 \%$ and photofase of $12 \mathrm{~h}$, in jack bean plants (Canavalia ensiformis). The bioassay was carried out approximately 60 days after transplanting $\mathrm{F}_{2}$ population, at room temperature and humidity in laboratory. The experimental design was completely randomized, with 12 treatments, corresponding to six plants with high content of ZGB, three plants with low content, parents (Redenção and PI-127826) and $F_{1}$ with four replications totalizing 48 leaflets (one leaflet per plot). Four young expanded leaflets were collected from the upper third and fixed with the aid of a metal thumbtack ( $9 \mathrm{~mm}$ in diameter) in the central region of adaxial leaf surface, on an offset sheet of paper, on a styrofoam plate. Leaflets were distributed randomly on a styrofoam plate, forming a replication. Ten female mites were collected from the controlled nursery and transferred to the center of each thumbtack, with the aid of a fine brush. The average distances traveled by mites (in $\mathrm{mm}$ ) on the surface of each leaflet were measured from the center of the thumbtack, after 20, 40 and 60 minutes. Shorter distances traveled 
by mites were considered indicative of higher levels of resistance. The authors considered zero the distance traveled by the mites which remained on the thumbtack and they considered the greater distance from the tack to the leaf edge when the spider mite left the adaxial leaf surface.

Experiment 3 - Resistance to whitefly - for the evaluations of resistance to whitefly (Bemisia tabaci Biotype B), one population of this insect was maintained in a greenhouse in the Sector of Vegetable Crops of Midwest Paraná State University, in sweet potato (Ipomoea batata). Approximately 35 days after cloning, the contrasting plants selected in relation to ZGB content, along with parents and $F_{1}$ plants, were submitted to infested environment. The experimental design was completely randomized, with 12 treatments, corresponding to six $\mathrm{F}_{2}$ plants with high content of ZGB, three $\mathrm{F}_{2}$ plants with low content, parents (Redenção and PI-127826) and $\mathrm{F}_{1}$, with four replications totalizing 36 plants (one plant per plot). After 48 hours of submission to the infested environment, these plants were removed and taken to another greenhouse, where the first evaluation was carried out. This evaluation consisted of the collection of three leaflets, one from the upper third, one from the middle third and another from the lower third of each plant. The leaves from where the leaflets were collected were identified in order to be collected leaflets of the same leaves evaluated, in the next evaluation. In the evaluation, the authors counted the number of eggs in $2 \mathrm{~cm}^{2}$ leaf area of the leaflet abaxial face, with the aid of a stereoscopic microscope. Twenty days after infestation, leaflets were collected again and evaluated for oviposition and number of the last instar nymphs, in $2 \mathrm{~cm}^{2}$ of leaf area of leaflet abaxial faces, also with the aid of stereoscopic microscope.

The data obtained in these experiments were subjected to analysis of variance and the averages were compared through Scott-Knott test, using the statistical program SISVAR (Ferreira, 2008). Pearson correlations were estimated to verify the association between ZGB contents and resistance of the plants. The significance of correlations was calculated by the $t$ test, with the aid of Assistat software.

For carried out trials, the authors estimated contrasts of interest among parental and plant groups with contrasting ZGB contents. Statistical software SISVAR (Ferreira, 2008) was also used for this analysis.

\section{RESULTS AND DISCUSSION}

Plants selected in experiment 1 for high and low ZGB content are shown in Table 1.

In experiment 2 , in which the authors evaluated the resistance to spider mite, selected plants showed significant and negative correlation between the distance traveled by mites in 20, 40 and 60 minutes, and ZGB content quantified in leaflets. This fact shows that as ZGB content in the leaflets increases, the average distance traveled by spider mite decreases (Table 1).

Significant difference between distances traveled by the spider mite on the leaf surface of plants, selected for high and low ZGB content, $\mathrm{F}_{1}$ generation and parents, was noticed. The distances observed in plants selected for high ZGB content differed from the wild accession PI-127826, however

Table 1. Mean distance travelled ( $\mathrm{mm})$ by T. urticae and estimate of the contrasts of interest among tomato progenies after 20,40 and 60 minutes of exposure to the adaxial surface of leaflets genotype $S$. lycopersicum cultivar Redenção, S. habrochaites var. hirsutum (PI127826), $F_{1}$ generation and selected $F_{2}$ plants with high and low ZGB content (distâncias médias percorridas $(\mathrm{mm})$ por $T$. urticae e estimativa dos contrastes de interesse entre as progênies de tomateiro após 20, 40 e 60 minutos de exposição à superfície adaxial dos folíolos de genótipos S. lycopersicum cultivar Redenção, S. habrochaites var hirsutum (PI127826), geração $F_{1}$ e progênies selecionadas da geração $F_{2}$ com alto ou baixo teor de ZGB). Guarapuava, UNICENTRO, 2014.

\begin{tabular}{|c|c|c|c|c|}
\hline \multirow{2}{*}{ Genotypes } & \multirow{2}{*}{$\begin{array}{c}\text { Zingiberene } \\
\text { content (Abs) }{ }^{1}\end{array}$} & \multicolumn{3}{|c|}{ Distance travelled $(\mathrm{mm})$} \\
\hline & & $20 \mathrm{~min}$ & $40 \mathrm{~min}$ & $60 \mathrm{~min}$ \\
\hline PI-127826 & 1.099 & $0.73^{2} \mathrm{a}$ & $1.16^{2} \mathrm{a}$ & $1.03^{2} \mathrm{a}$ \\
\hline RVTZ pl\#79 (high) & 0.715 & $10.25^{2} \mathrm{~b}$ & $7.37^{2} \mathrm{a}$ & $8.16^{2} \mathrm{~b}$ \\
\hline RVTZ pl\#141 (high) & 0.719 & $9.90^{2} \mathrm{~b}$ & $11.20^{2} \mathrm{~b}$ & $11.19^{2} \mathrm{~b}$ \\
\hline RVTZ pl\#142 (high) & 0.813 & $7.68^{2} \mathrm{~b}$ & $5.25^{2} \mathrm{a}$ & $5.80^{2} \mathrm{a}$ \\
\hline RVTZ pl\#143 (high) & 0.592 & $9.37^{2} \mathrm{~b}$ & $10.93^{2} \mathrm{~b}$ & $10.91^{2} \mathrm{~b}$ \\
\hline RVTZ pl\#277 (high) & 0.747 & $11.02^{2} \mathrm{~b}$ & $13.97^{2} \mathrm{~b}$ & $14.36^{2} \mathrm{~b}$ \\
\hline RVTZ pl\#331 (high) & 0.746 & $9.90^{2} \mathrm{~b}$ & $11.21^{2} \mathrm{~b}$ & $13.05^{2} \mathrm{~b}$ \\
\hline RVTZ pl\#09 (low) & 0.247 & $20.08^{2} \mathrm{c}$ & $21.93^{2} \mathrm{~d}$ & $23.16^{2} \mathrm{c}$ \\
\hline RVTZ pl\#189 (low) & 0.263 & $13.38^{2} \mathrm{~b}$ & $17.37^{2} \mathrm{c}$ & $19.20^{2} \mathrm{c}$ \\
\hline RVTZ pl\#365 (low) & 0.210 & $19.76^{2} \mathrm{c}$ & $21.22^{2} \mathrm{~d}$ & $26.80^{2} \mathrm{~d}$ \\
\hline Redenção & 0.084 & $21.35^{2} \mathrm{c}$ & $25.27^{2} \mathrm{~d}$ & $28.01^{2} \mathrm{~d}$ \\
\hline $\mathrm{F}_{1}$ (Redenção X PI-27826) & 0.145 & $8.16^{2} \mathrm{~b}$ & $16.00^{2} \mathrm{c}$ & $19.13^{2} \mathrm{c}$ \\
\hline Correlation & & $-0.78^{*}$ & $-0.89 *$ & $-0.91 *$ \\
\hline \multicolumn{2}{|c|}{ Identification of contrasts of interest } & \multicolumn{3}{|c|}{ Estimate } \\
\hline \multicolumn{2}{|c|}{$\mathrm{C} 1=$ plants (high ZGB) $\times$ plants (low ZGB) } & $-7.55^{* *}$ & $-10.19 * *$ & $-13.46^{* *}$ \\
\hline \multicolumn{2}{|c|}{$\mathrm{C} 2=\mathrm{PI}-127826 \times$ plants (high ZGB) } & $-8.96 * *$ & $-8.83 * *$ & $-9.55 * *$ \\
\hline \multicolumn{2}{|c|}{ C3= PI-127826 x plants (low ZGB) } & $-17.01 * *$ & $-8.83 * *$ & $-22.03 * *$ \\
\hline \multicolumn{2}{|c|}{ C4= Redenção $x$ plants (high ZGB) } & $11.66^{* *}$ & $15.28 * *$ & $17.43 * *$ \\
\hline \multicolumn{2}{|c|}{ C5= Redenção x plants (low ZGB) } & 3.61 & 5.10 & 4.96 \\
\hline
\end{tabular}

${ }^{1}$ Zingiberene content at $270 \mathrm{~nm} ;{ }^{2}$ Means followed by the same letter in column belong to the same group by Scott-Knott, $5 \%$ (medias seguidas de letras iguais na coluna pertencem ao mesmo grupo, teste Scott-Knott, 5\%); *significant by Student 5\%; **significant by mean comparison test at 5\% (significativo pelo teste de comparação a 5\%). 
Table 2. Mean number of eggs and nymphs of B. tabaci on the abaxial leaflet face and estimate of the contrasts of interest among tomato plants after 48 hours and 20 days in the environment infested with whitefly for genotypes $S$. lycopersicum cultivar Redenção, S. habrochaites var. hirsutum (PI-127826), $\mathrm{F}_{1}$ generation and $\mathrm{F}_{2}$ selected plants (número médio de ovos e ninfas de $B$. tabaci na face abaxial de folíolos e estimativa dos contrastes de interesse entre as progênies de tomateiro após 48 horas e 20 dias em ambiente infestado com mosca-branca nos genótipos S. lycopersicum cultivar Redenção, S. habrochaites var hirsutum (PI-127826), geração $F_{1}$ e progênies selecionadas da geração $F_{2}$ ). Guarapuava, UNICENTRO, 2014.

\begin{tabular}{|c|c|c|c|c|}
\hline \multirow[b]{2}{*}{ Genotypes } & \multirow[b]{2}{*}{$\begin{array}{c}\text { Zingiberene } \\
\text { content }(\mathrm{Abs})^{1}\end{array}$} & \multirow{2}{*}{$\begin{array}{c}48 \text { hours } \\
\text { Number } \\
\text { of eggs }\end{array}$} & \multicolumn{2}{|c|}{20 days } \\
\hline & & & $\begin{array}{c}\text { Number } \\
\text { of eggs }\end{array}$ & $\begin{array}{c}\text { Number of } \\
\text { nymphs }\end{array}$ \\
\hline PI-127826 & 1.099 & $9.00^{2} \mathrm{a}$ & $10.89^{2} \mathrm{a}$ & $11.22^{2} \mathrm{a}$ \\
\hline RVTZ clone pl\#79 (high) & 0.715 & $7.00^{2} \mathrm{a}$ & $5.44^{2} \mathrm{a}$ & $8.44^{2} \mathrm{a}$ \\
\hline RVTZ clone pl\#141 (high) & 0.719 & $10.44^{2} \mathrm{a}$ & $10.11^{2} \mathrm{a}$ & $14.33^{2} \mathrm{a}$ \\
\hline RVTZ clone pl\#142 (high) & 0.813 & $9.00^{2} \mathrm{a}$ & $9.66^{2} \mathrm{a}$ & $4.89^{2} \mathrm{a}$ \\
\hline RVTZ clone pl\#143 (high) & 0.592 & $10.55^{2} \mathrm{a}$ & $3.77^{2} \mathrm{a}$ & $11.33^{2} \mathrm{a}$ \\
\hline RVTZ clone pl\#277 (high) & 0.747 & $19.33^{2} \mathrm{a}$ & $3.00^{2} \mathrm{a}$ & $12.78^{2} \mathrm{a}$ \\
\hline RVTZ clone pl\#331 (high) & 0.746 & $10.89^{2} \mathrm{a}$ & $5.89^{2} \mathrm{a}$ & $5.33^{2} \mathrm{a}$ \\
\hline RVTZ clone pl\#09(low) & 0.247 & $15.77^{2} \mathrm{a}$ & $33.55^{2} \mathrm{~b}$ & $36.77^{2} \mathrm{~b}$ \\
\hline RVTZ clonepl\#189(low) & 0.263 & $32.66^{2} \mathrm{~b}$ & $48.11^{2} \mathrm{~b}$ & $39.00^{2} \mathrm{~b}$ \\
\hline RVTZ clone pl\#365(low) & 0.210 & $54.55^{2} \mathrm{c}$ & $58.55^{2} \mathrm{~b}$ & $77.89^{2} \mathrm{c}$ \\
\hline Redenção & 0.084 & $54.33^{2} \mathrm{c}$ & $52.55^{2} \mathrm{~b}$ & $59.55^{2} \mathrm{c}$ \\
\hline $\mathrm{F}_{1}($ Redenção x PI-127826) & 0.145 & $10.44^{2} \mathrm{a}$ & $6.66^{2} \mathrm{a}$ & $14.33^{2} \mathrm{a}$ \\
\hline Correlation & & $-0.65^{*}$ & $-0.70 *$ & $-0.71^{*}$ \\
\hline \multicolumn{3}{|c|}{ Identification of contrasts of interest } & \multicolumn{2}{|l|}{ Estimate } \\
\hline \multicolumn{3}{|c|}{ 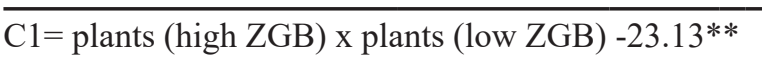 } & $-40.43 * *$ & $-41.70 * *$ \\
\hline \multicolumn{2}{|c|}{$\mathrm{C} 2=\mathrm{PI}-127826 \times$ plants (high ZGB) } & -2.20 & 4.57 & 1.70 \\
\hline \multicolumn{2}{|c|}{ C3 $=$ PI-127826 x plants (low ZGB) } & $-25.33 * *$ & $-35.85 * *$ & $-40.00 * *$ \\
\hline \multicolumn{2}{|c|}{ C4= Redenção x plants (low ZGB) } & $43.13 * *$ & $46.24 * *$ & $50.04 * *$ \\
\hline \multicolumn{2}{|c|}{ C5= Redenção x plants (low ZGB) } & 20.00 & 5.81 & 8.33 \\
\hline
\end{tabular}

${ }^{1}$ Zingiberene content at $270 \mathrm{~nm} ;{ }^{2}$ Means followed by the same letter in column belong to the same group by Scott-Knott, $5 \%$ (medias seguidas de letras iguais na coluna pertencem ao mesmo grupo, teste Scott-Knott, 5\%); *significant by Student 5\%; **significant by mean comparison test at $5 \%$ (significativo pelo teste de comparação a $5 \%$ ).

they showed averages lower than the plants with low content (contrast $\mathrm{C} 1$ and $\mathrm{C} 2$, Table 1). Significant and negative values of estimated contrasts $\mathrm{C} 1$ and $\mathrm{C} 2$ highlight opposite behavior between plants with high and low content for distance traveled by spider mite on the leaflet surface, allowing, therefore, inference that high contents of the allelochemical promote greater resistance to spider mite.

The plants selected for low content showed higher averages of distances traveled than the plants selected for high ZGB content, similar to accession S. lycopersicum cultivar Redenção and to $\mathrm{F}_{1}$ (contrasts $\mathrm{C} 1$ and $\mathrm{C} 5$, Table 1). Positive and no significant values distance traveled on the leaf surface of plants with low allelochemical contents, since high ZGB content inhibit the drive of spider mite (Table 1).

The plant RVTZ pl\#142 stood out as one of the most promising lines, showing averages similar to accession PI-127826 in the evaluations of 40 and 60 minutes, showing greater resistance to spider mite.

The results are in accordance with Maluf et al. (2007) and Silva et al. (2009) showing that the high ZGB allelochemical contents provide resistance to spider mite. The study states that resistance provided by high ZGB content is directly related to high density of glandular trichomes on leaflet surface.

In experiment 3 , in which the authors evaluated resistance to whitefly, significant difference between the plants in evaluations carried out was also observed (Table 2).

The plants selected for the high ZGB content did not differ from PI-127826, showing resistance to whitefly. On the other hand, the plants selected for low allelochemical contents showed results similar to the susceptible accession, cultivar Redenção (Table 2). This fact shows that the presence of high ZGB content in the leaflets acts effectively in the resistance of the plant to whitefly.

There were significant and negative correlation between oviposition and number of eggs and nymphs, and ZGB content (Table 2). Thus, the increase of ZGB content causes reduction in insect population on the plants. These results are similar to ones found by Freitas et al. (2002) and Neiva et al. (2013), in which high ZGB content provided resistance to whitefly.

These results are in accordance with that found by Azevedo et al. (2003); Maluf et al. (2007, 2010), Oliveira et al. (2012) and Neiva et al. (2013) who verified that high ZGB contents, together with high density of glandular trichomes, promote resistance of plants to spider mite, whitefly and tomato leafminer. According to Gonçalves et al. (2006), high ZGB content is directly linked to high density of glandular trichomes.

Genetic gains, related to resistance 
to these arthropod pests, when selection for high ZGB content is done, can be expected in breeding programs which aim to obtain resistant cultivars, since heritability for ZGB content is high (67.8\%) (Freitas et al., 2002).

Indirect selection of plants in relation to $\mathrm{ZGB}$ content shows to be highly efficient in selecting plants resistant to spider mite and whitefly. Plants selected for high content will be retrocrossed with recurrent genitor (S. lycopersicum 'Redenção') for the continuity of the breeding program and to obtain commercial genotypes, resistant to arthropod pests.

The results obtained confirm that indirect selection of plants with high ZGB content is efficient to obtain tomato plants for processing, resistant to arthropod pests, as spider mite ( $T$. urticae) and whitefly (B. tabaci) herein evaluated.

\section{ACKNOWLEDGEMENT}

The authors thank Fundação Araucária de Apoio ao Desenvolvimento Científico e Tecnológico do Paraná (Foundation for Support on Scientific and Technological Development of Paraná State) for financial support, the Conselho Nacional de Desenvolvimento Científico e Tecnológico (CNPq) (National Council for Scientific and Technological Development) for the Research Incentive scholarships granted and Coordenação de Aperfeiçoamento de Pessoal de Nível Superior (CAPES) (Coordination for Improvement of Higher Education Personnel) for Master scholarship granted.

\section{REFERENCES}

AZEVEDO, SM; FARIA, MV; MALUF, WR; OLIVEIRA, ACB; FREITAS, JA. 2003. Zingiberene-mediated resistance to the South American tomato pinworm derived from Lycopersicon hirsutum var. hirsutum. Euphytica 134: 347-351.

CAMARGO, AMMP; CAMARGO, FP; ALVES, HS; CAMARGO FILHO, WPC. 2006. Desenvolvimento do sistema agroindustrial de tomate. Informações Econômicas 36: 53-65.

FERRAZ, E, RESENDE, LV; LIMA, GSA; SILVA, MCL; FRANÇA, JGE; SILVA, DJ. 2003. Redenção: nova cultivar de tomate para a indústria resistente a geminivírus e tospovírus. Horticultura Brasileira 21: 578-580.

FERREIRA，D. 2008. SISVAR: um programa para análises e ensino de estatística. Symposyum 6: 36-41.

FREITAS, JA; MALUF, WR; CARDOSO, MG; BENITES, FRG. 2000. Métodos para quantificação do zingibereno em tomateiro, visando à seleção indireta de plantas resistentes aos artrópodes praga. Acta Scientiarum 22: 943-949.

FREITAS, JA; MALUF, WR; CARDOSO, MG; GOMES, LAA; BEARZOTTI, E. 2002. Inheritance of foliar zingiberene contents and their relationship to trichome densities and whitefly resistance in tomatoes. Euphytica 127: 275-287.

GONÇALVES, LD; MALUF, WR; CARDOSO, MG; RESENDE, JTV; CASTRO, EM; SANTOS, NM; NASCIMENTO, IR; FARIA, MV. 2006. Relação entre zingibereno, tricomas foliares e repelência de tomateiros a Tetranychus evansi. Pesquisa Agropecuária Brasileira 41: 267-27.

INSTITUTO AGRONÔMICO DE CAMPINAS. 1996. Boletim Técnico 100: Recomendações de Adubação e Calagem para o Estado de São Paulo. Campinas, SP. 285p.

LUCINI, T; FARIA, MV; ROHDE, C; RESENDE, JTV; OLIVEIRA, JRF. 2015. Acylsugar and the role of tricomes in tomato genotypes resistance to Tetranychus urticae. Arthopod-Plant Interactions 9: 45-53.

MALUF, WR; CAMPOS, GA; CARDOSO, MG. 2001. Relationships between trichome types and spider mite (Tetranychus evansi) repellence in tomatoes with respect to foliar zingiberene contents. Euphytica 121: 73-80.

MALUF, WR; INOUE, IF; FERREIRA, RPD; GOMES, LAA; CASTRO, EM; CARDOSO, MG. 2007. Higher glandular trichome density in tomato leafletsand repellence to spider mites. Pesquisa Agropecuária Brasileira 42: 1227-1235.

MALUF, WR; SILVA, VF; CARDOSO, MG; GOMES, LAA; GONÇALVES NETO, AC; MACIEL, GM; NÍZIO, DAC. 2010. Resistance to the South American tomato pinworm Tuta absoluta in high acylsugar and/or high zingibereno tomato genotypes. Euphytica 176:113123.

NASCIMENTO, LN; SILVA, AR; ZAGATI, FQ. 2013. Tomate de vilão a mocinho. Hortifruti Brasil 130: 31-34.

NEIVA, IP; ANDRADE JÚNIOR, VC; MALUF, WR; OLIVEIRA, CM; MACIEL, GM. 2013. Role of allelochemicals and trichome density in the resistance of tomato to whitefly. Ciência e Agrotécnologia 37: 61-67.

OLIVEIRA, CM; ANDRADE JUNIOR, VC; MALUF, WR; NEIVA, IP; MACIEL, GM. 2012. Resistance of tomato strains to the moth Tuta absoluta imparted by allelochemicals and trichome density. Ciência e Agrotecnologia 36: 45-52.

SILVA, VF; MALUF, WR; CARDOSO, MG; GONÇALVES NETO, AC; MACIEL, GM; NÍZIO, DAC; SILVA, VA. 2009. Resistência mediada por aleloquímicos de genótipos de tomateiro à mosca-branca e ao ácaro-rajado. Pesquisa Agropecuária Brasileira 44: 1262-1269.

TOSCANO, LC; BOIÇA JÚNIOR, AL; MARUYAMA, WI. 2004. Assessment of physiological aspects of three tomato genotypes infested by Bemisia tabaci Gennadius biotype B (Hemiptera: Aleyrodidae). Neotropical Entomology 33: 777-782.

WESTON, PA; JOHNSON, DA; BURTON, HT; SNYDER, JC. 1989. Trichome secretion composition, trichome densities, and spider mite resistance of ten accessions of Lycopersicon hirsutum. Journal of tre American Society for Horticultural Science 114: 492-498.

WESTON, PA; SNYDER, JC. 1990. Thumbtack bioassay: a quick method of measuring plant resistance to twospotted spider mites (Acari: Tetranychidae). Journal of Economic Entomology 83: 501-504.

WPTC - World Processing Tomato Council. 2014, 09 de maio. World production estimate of tomatoes for processing. Disponível em: http://www.wptc.to/ pdf/relea,5ses/WPTC\%20World $\% 20$ Production $\% 20$ estimate $\% 20$ as $\% 20$ of $\% 203 \% 20$ April $\% 202014$.pdf 